\title{
Beneficial effect of Hordeum vulgare extract against aluminum chloride induced neurotoxicity in Wistar rats
}

\author{
Hadj Fidah* \\ Laboratory of Biotoxicology, Pharmacognosy and Biological Valorisation of plants (LBPVBP) \\ Department of Biology, Faculty of Natural and Life Sciences, University of Dr Moulay Tahar- \\ Saida-Algeria \\ Kadda Hachem \\ Laboratory of Biotoxicology, Pharmacognosy and Biological Valorisation of plants (LBPVBP) \\ Department of Biology, Faculty of Natural and Life Sciences, University of Dr Moulay Tahar- \\ Saida - Algeria \\ Djallal Eddine Adli \\ Laboratory of Biotoxicology, Pharmacognosy and Biological Valorisation of plants (LBPVBP) \\ Department of Biology, Faculty of Natural and Life Sciences, University of Dr Moulay Tahar- \\ Saida-Algeria

\section{Mostapha Brahmi} \\ Laboratory of Biotoxicology, Pharmacognosy and Biological Valorisation of plants (LBPVBP) \\ Department of Biology, Faculty of Natural and Life Sciences, University of Dr Moulay Tahar- \\ Saida-Algeria

\section{Hemida Houari} \\ Institute of Veterinary Sciences, University of Tiaret, Algeria \\ Khaled Kahloula \\ Laboratory of Biotoxicology, Pharmacognosy and Biological Valorisation of plants (LBPVBP) \\ Department of Biology, Faculty of Natural and Life Sciences, University of Dr Moulay Tahar- \\ Saida-Algeria \\ Miloud Slimani \\ Laboratory of Biotoxicology, Pharmacognosy and Biological Valorisation of plants (LBPVBP) \\ Department of Biology, Faculty of Natural and Life Sciences, University of Dr Moulay Tahar- \\ Saida-Algeria \\ ${ }^{*}$ Corresponding author: E. mail: hadjfidah@yahoo.fr
}

\section{How to Cite}

Fidah, H. et al. (2020). Beneficial effect of Hordeum vulgare extract against aluminum chloride-induced neurotoxicity in Wistar rats. Journal of Applied and Natural Science, 12(3): 422 - 429. https://doi.org/10.31018/jans.v12i3.2344

\begin{abstract}
Aluminum is present in medicines and food. Its toxicity induces deleterious effects in various living organisms. At the same time, Hordeum vulgare a cereal known as an important nutritional source and also endowed with bioactive molecules. The objective of this study was to evaluate, on the one hand, the modifications induced by aluminum chloride in Wistar rats at the cerebral level and, on the other hand, to test the efficacy of the barley extract, Hordeum vulgare, (HEV) to restore the harmful effects of this studied metal with a concentration of $13 \mathrm{ml} \mathrm{HEV/kg/day} \mathrm{for} \mathrm{a} \mathrm{period} \mathrm{of} 21$ days. The extraction of HEV by maceration resulted in an aqueous extract with a yield of $10.70 \%$. Exposure to $\mathrm{AlCl} 3$ at a concentration of $100 \mathrm{mg} / \mathrm{kg}$, permitted to observe that the concentration of aluminium at the brain level is significantly high $(p<0.05)$ in the intoxicated rats compared to the control rats. On the other hand, the activity of alkaline phosphatase (PAL), superoxide dismutase (SOD), catalase (CAT), and glutathione peroxidase (GPX) indicated a decrease in the intoxicated rats. Indeed, the histological study showed very pronounced lesions in the brains of the poisoned rats resulting in necrosis and cellular spongiosis. In addition, the administration of HEV restored the activity of the various antioxidant enzymes with an improvement in brain tissue architecture in intoxicated rats treated with HEV which justifies the therapeutic virtues of $H$. vulgare in protecting against aluminium chloride-induced neurotoxicity.
\end{abstract}

Keywords: Aqueous Extract, Antioxidant status, AICl3, Hordeum vulgare, Brain

\section{INTRODUCTION}

Aluminum is an abundant metallic element on earth and is very used because of its excellent properties (Bai et al. 2012). It represents $8 \%$ of the earth's miner- 
als. In food its maximum content is not fixed. Aluminum can be used in the preparation of some medicines (Turkez et al. 2010), used in water clarification (flocculation, coagulation, etc.), in materials in contact with food and used as a food additive. It is found in drinking water at a maximum concentration of $0.2 \mathrm{mg} / \mathrm{l}$ (Afssaps ,2011). In mammals, aluminum accumulates in the kidneys, liver, heart, blood, bones and brain (AlKahtani, 2010). There is experimental evidence that chronic exposure to aluminum not only causes neurological signs resembling progressive degeneration but also leads to changes in neurofilaments in the hippocampus, cerebral cortex, brain stem and spinal cord (Liaquat et al., 2019). The aluminum can produce free radicals in the body. It induces a toxic effect due to its ability to transfer electrons. Aluminum is known to affect the permeability of cell membranes, subcellular organelles, the structure and functions of proteins and the structure of nucleic acids (Taus et al., 2013).

The barley is of the Poaceae family and the Hordeum species, the most common form being Hordeum vulgare. It is considered to be one of the most important food grains since antiquity and today. It ranks fourth in the world in terms of quantity produced and area under cereal cultivation (Zhou, 2010). Barley is a nutritious cereal with many bioactive elements that are beneficial to health. Much research has shown that barley has been associated with protection against diabetes, insulin resistance, ischemic stroke, atherosclerosis, obesity and cancer (Behall et al., 2004; FDA, 2002). Grains contain many nutrients, including dietary fibre, antioxidants (soluble, fat-soluble and insoluble), vitamins, minerals (calcium, magnesium, potassium, phosphorus), sphingolipids and unsaturated fatty acids (Webster, 2002; Murtaugh et al., 2003).

The present study was aimed to observe the impact of aluminum chloride exposure at the brain level in Wistar rats, after testing the effect of the aqueous extract of the plant Hordeum vulgare attenuated neurotoxicity in rats intoxicated by this metal.

\section{MATERIALS AND METHODS}

Preparation of the plant extract: Our work focuses on the plant $H$. vulgare, which was identified by taxonomic experts (Sitayeb and Belabbes,2018). The sample was preserved, and the specimen voucher, coded P-201690, has been deposited in the herbarium of the Biology Department of the Faculty of Science of the University of Saida, Algeria, for future reference.

Then, in a monocle flask topped with a refrigerant, $10 \mathrm{~g}$ of the plant material and trickled with $100 \mathrm{ml}$ of distilled water brought to boiling for 30 minutes, filtered the mixture and recovered the filtrate, (readjust the volume to $100 \mathrm{ml}$ ) (Rebaya et al., 2014).
Origin of the animals and housing conditions: The number of suffering animals were minimized in accordance with the guidelines of the European Council Directive (86/609/EEC).

The experiments were carried out on albino rats of Wistar strain, from the local animal house of the university, Dr. Moulay Tahar, Saida, Department of Biology. The animals were housed in professional plastic cages $(43 \times 28 \times 15 \mathrm{~cm})$ at the pet shop. The room they occupied was maintained at a temperature of (22 to 23 $\mathrm{C}^{\circ}$ ) and was subjected to a constant light cycle (alternating 12 hours of darkness and 12 hours of light). The animals focused Ad libitum at the water bottles and feeders.

Distribution of lots: The animals in our experiment were divided into three groups of 7 rats each.

Control lot (C): Consisting of 7 rats receiving only distilled water orally.

AICl3 lot: Consisting of 7 rats receiving $100 \mathrm{mg} / \mathrm{kg}$ Aluminum chloride in distilled water orally for 12 weeks (Kumar et al., 2009)

AICl3-HEV lot: Consisting of 7 rats receiving aluminum chloride in distilled water orally and H.vulgare aqueous extract at $13 \mathrm{ml} / \mathrm{kg}$ by gavage for 21 days (Aldalain et al.,2008).

\section{Biochemical tests}

Determination of the level of aluminum in the brain: After weaning and treatment with $H$. vulgare extract, the animals are decapitated and whole blood samples $(100 \mu \mathrm{l})$ are recovered in a $5 \mathrm{ml}$ haemolysis tube containing $100 \mu \mathrm{l}$ of $0,1 \%$ newt. After vortex agitation for 30 seconds, deproteinization was achieved by adding $600 \mu \mathrm{l}$ of HNO3 $(1 \mathrm{M})$. This was followed by a second vortex agitation of the tube contents for 10 minutes at room temperature. The next step was centrifugation of the total tube container at $3000 \mathrm{rpm}$ for 10 minutes. In the end, the blood lead level was determined by a type Atomic absorption spectrophotometer (SHIMA DZU AA6200)

Measurement of alkaline phosphatase: The brains of the rats were placed in a $4 \mathrm{ml}$ Potter-Elvehjem homogenizer. Homogenization was carried out in ten volumes of $0,32 \mathrm{M}$ sucrose ice solution. The whole homogenate and the rinsing liquid are centrifuged at 1 $000 \mathrm{~g}$ for 10 minutes at $4{ }^{\circ} \mathrm{C}$. The supernatant thus represented a crude synaptosomal fraction which was removed and kept in ice for enzyme determination (Adli et al., 2018).

Alkaline phosphatase (PAL) was estimated using the following reaction:

- p-nitrophenylphosphate + H 2 O; - phosphate + pnitrophenol.

The concentration of p-nitrophenyl released is proportional to the activity of PAL and is measured photometrically at a wavelength of $405 \mathrm{~nm}$. 
Measuring the activity of antioxidant enzymes: The brains of the recovered rats were homogenized in a Buffer solution containing $0.5 \mathrm{mM}$ EDTA, $10 \mathrm{mM}$ Tris$\mathrm{HCl}(\mathrm{pH}: 7.4) 0.32 \mathrm{M}$ sucrose, at $4^{\circ} \mathrm{C}(1 \mathrm{mg}$ tissue per $4 \mathrm{ml}$ buffer solution) using a glass/glass homogenizer. The homogenate was centrifuged at $1000 \times \mathrm{g}$ for 15 minutes at $4^{\circ} \mathrm{C}$. The resulting supernatant was then centrifuged at $10000 \times \mathrm{g}$ for 15 minutes at $4{ }^{\circ} \mathrm{C}$. The pellet constitutes the mitochondrial fraction, and the supernatant was re-centrifuged at $10 \quad 000 \mathrm{~g} / 30$ minutes. The two pellets thus obtained are solubilized in a buffer solution containing 0,5 mM EDTA, $10 \mathrm{mM}$ Tris- $\mathrm{HCl}(\mathrm{pH} 7,4), 0,32 \mathrm{M}$ sucrose and $0,02 \%$ digitonin $(\mathrm{pH} 7,4)$; a second pellet was made at $10000 \times \mathrm{g}$ for 15 minutes at $4{ }^{\circ} \mathrm{C}$. The second pellet was centrifuged at $10000 \times \mathrm{g}$ for 15 minutes at $4{ }^{\circ} \mathrm{C}$. Finally, the pellet obtained, which constitutes the total fraction of mitochondria, will be solubilized in a sucrosecontaining solution $(0.32 \mathrm{M}$ at $\mathrm{pH}=7.4$ ) (Rotruck et al., 1973). Superoxide dismutase (SOD) [EC 1.15.1.1] was analyzed on the supernatant using the technique of Kakkar et al. (1984),

The activities and levels of antioxidant enzymes in the brain,such as glutathione peroxidase (GPx) and catalase (CAT) were analyzed by the method of Rotruck et al (1973),Sinha (1972) and Jollow et al (1973).

Histological study: After sacrifice, brain samples were collected from all groups of rats and fixed in a buffered solution of formalin (10\%), dehydrated in ascending grades of ethanol $(70-100 \%)$, clarified in $x y-$ lene and cast (the paraffin), blocked, cut to a thickness of $5 \mu \mathrm{m}$, routinely stained with haematoxylin and eosin (H\&E) dyes (Bancroft, 1975) and examined microscopically at magnification $(\times 40)$.

Expression and statistical analysis of results: The results were expressed as the mean (M) of the individual values, assigned the standard error to the mean (SEM). The comparison of several means was carried out by an analysis of variance (ANOVA) with the intoxication factor (Al, C) and/or the treatment factor (HEV, Al) followed possibly by the Post-Hoc StudentNewman-Keuls test: A probability ${ }^{*} p \leq 0.05$ indicates a significant difference. ${ }^{* *} p<0.01$; indicates a highly significant difference; ${ }^{* * *} p<0.001$ indicates a highly significant difference compared to controls. Statistical analyses were performed using Sigma Stat software (SPSS Inc., Chicago, IL, USA).

\section{RESULTS AND DISCUSSION}

Extract yield and principal compounds: The extraction of plant matter from Hordeum vulgare resulted in a yield of $10.70 \%$. This result is at variance with the work of Abu-Serie et al., (2019), which reported a return of $12.27 \%$. This difference in yield can be attributed to several factors, mainly the geographical origin of the plants and pedoclimatic conditions (Sefidkon, 2002).

Determination of Alcl3 and PAL at brain level: The results showed that Alcl3 concentration in the brain was significantly elevated $(p<0.05)$ in the intoxicated rats compared to the control rats (Table 1). This accumulation in the brain confirms the capacity of Alcl3 to penetrate the blood-brain barrier (Chalansonnet et al., 2018). In addition, there are reports that aluminium can accumulate in various human organs such as the brain and bones (Abdel-Wahab, 2012; Kalaiselvi et al., 2014). Other studies have indicated that a concentration of aluminum chloride (34 mg/kg bw) induced neurotoxicity and accumulation in the brain in adult male albino Wistar rats that were injected with $\mathrm{AICl} 3$ for 7 days (Yuan et al.,2012).

Sanchez-lglesias et al. (2007) identified aluminum accumulation in the ventral midbrain, cerebellum, hippocampus, cortex and striatum of rats after treatment with aluminum chloride by oral administration or intraperitoneal injection. In addition, Domingo et al. (1996) showed that administration of aluminum nitrate with doses of 0.50 and $100 \mathrm{mg} / \mathrm{kg}$ body weight $/ \mathrm{d}$ in drinking water over a period of 6.5 months accumulated in the olfactory bulb, cortex, and thalamus in rats.

PAL is one of the key enzymes that indicate central nervous system (CNS) function, and its activity will allow further study of the impact of neurotoxicity in rats. This enzyme is synthesized at the choroid plexus, and its membrane localization at synapses and Ranvier's nodes, as well as its activity regulated by the level of afferent activity and neuronal maturation suggest an important role in nerve impulse transmission and regulation (Fonta et al.,2005). Results indicate that PAL activity, which reflects neurotoxicity in rats, is significantly lower in the brains of $\mathrm{AlCl} 3$-exposed rats compared with non-exposed rats (Table 1).

Brain activity of oxidative status enzymes: The high concentration of transition metals has the potential to cause an overproduction of nitrogen and oxygen free radicals in the body, and they are likely to react near their formed location. If these free radicals do not neutralize themselves, oxidative damage forms in the subcellular systems and this are due to the incapacity of the cellular defense system. As a result, aluminum chloride is a transition metal and has the potential to modify the activity of enzymatic antioxidants. (AbdelWahab, 2012; Kalaiselvi et al., 2014).

In another series of experiments, the exploration of antioxidant enzymes at the brain level in rats exposed to $\mathrm{AICl} 3$ revealed considerable perturbations, with a significant $\left({ }^{*} p<0.05,{ }^{* * *} p<0.001\right)$ decrease in the activity of the different enzymes (CAT, GPx and SOD) compared to the control group (Table 2). These results show that exposure to $\mathrm{AICl} 3$ induces a reduction 
Table 1. Al levels and cerebral PAL activity in control, intoxicated and intoxicated rats treated with HEV.

\begin{tabular}{llll}
\hline $\begin{array}{l}\text { Brain con- } \\
\text { centration }\end{array}$ & Control & ALCL3 & $\begin{array}{l}\text { ALCL3- } \\
\text { HEV }\end{array}$ \\
\hline $\mathrm{Al}(\mu \mathrm{g} / \mathrm{g})$ & $0,96 \pm 0,18^{*}$ & $6,85 \pm 0,36^{*}$ & $4,29 \pm 0,25^{*}$ \\
$\mathrm{PAL}(\mu \mathrm{g} \mathrm{p}-$ & $3,66 \pm 0,34^{*}$ & $1,86 \pm 0,23^{*}$ & $2,19 \pm 0,56^{*}$ \\
nitrophenol/ & & & \\
mg protein/ & & & \\
minute) & & & \\
\hline
\end{tabular}

Values are expressed as mean \pm SEM; ${ }^{*} p<0.05$

Table 2: Cerebral antioxidant enzyme activity (SOD, GPx, CAT) in control, intoxicated and intoxicated rats treated with HEV.

\begin{tabular}{llll}
\hline $\begin{array}{l}\text { Brain con- } \\
\text { centration }\end{array}$ & Control & ALCL3 & AICI3 -HEV \\
\hline $\begin{array}{l}\text { SOD (U/mg } \\
\text { de protein) }\end{array}$ & $5,98 \pm 0,28^{* \star *}$ & $3,75 \pm 0,11^{* * *}$ & $4,51 \pm 0,44^{\star * \star}$ \\
$\begin{array}{l}\text { GPx (U/mg } \\
\text { de protein) }\end{array}$ & $19,44 \pm 0,17^{*}$ & $11,51 \pm 0,61^{*}$ & $13,92 \pm 0,21^{*}$ \\
$\begin{array}{l}\text { CAT (U/mg } \\
\text { de protein) }\end{array}$ & $0,76 \pm 0,34^{*}$ & $0,51 \pm 0,22^{*}$ & $0,59 \pm 0,85^{*}$ \\
\hline
\end{tabular}

Values are expressed as mean \pm SEM; ${ }^{* * *} p<0.001,{ }^{*} p<0.05$

in the activities of antiradical enzymes in the brain (Samet and Wages., 2018). The administration of aluminum chloride (AICl3; $34 \mathrm{mg} / \mathrm{kg}$ bw) showed a reduction in antioxidant enzymes (SOD, CAT and GPx) in albino Wistar rats (Al-Olayan et al., 2015).

Some studies have described that high Al levels can induce oxidative stress and cause lipid peroxidation in the cerebellum, brain stem, diencephalon and hippocampus. In these tissues, the production of antioxidant enzymes was expected to counteract oxidative stress. Other studies have shown that SOD activities decreased in the hippocampus, cerebellum and brainstem tissues of animals with high Alcl3 content. Several other studies that have also identified a significant decrease in SOD activities in the hippocampal region in rats (Sharma et al., 2009; Sánchez-Iglesias et al., 2009), cerebellum (Nehru and Anand, 2005; SánchezIglesias et al., 2009) and brainstem (Kaur et al., 2009; Sánchez-Iglesias et al., 2009) in high Alcl3 animals. Similar results were reported by Esparza et al. (2005). who illustrated that GPx activity was significantly higher in the cerebellum, hippocampus and brainstem in rats.

Histological study: Histological study of the cerebellum of $\mathrm{AlCl} 3$ intoxicated rats revealed very marked damage, with cellular necrosis and cellular spongiosis (Fig. 1).

Histological investigations revealed that exposure to $\mathrm{AlCl} 3$ caused progressive alterations of the brain. The results corroborated the previous findings of Abdel Moneim (2012) and Bhadauria (2012) as Alcl3 has been implicated in the pathogenesis of several clinical disorders and histopathological changes in the brain of rats.

Histopathological changes in the brain have been reported in several studies in rats for periods ranging from 21 days to 1 year following administration of drinking water or food to which aluminum salts $\{\mathrm{AICl} 3$, AlF3 or $\mathrm{C}_{6} \mathrm{H}_{5} \mathrm{AlO}_{7}$ (Al citrate)\} were added at varying doses (15, 20 et $40 \mathrm{mg} \mathrm{Al} / \mathrm{kg}$ ).

In some cases, cytoplasmic vacuolization, astrocyte swelling, and nuclear vacuolization of neurons and inclusions in the brain parenchyma (Liaquat et al., 2019) and in other studies, multifocal neuronal degeneration, damaged and abnormal neurons, and decreased neuronal density in certain brain regions (cerebral cortex, subcortical region, hippocampus and base of the brain) in rats (Al-Olayan et al., 2015)

Deformation, vacuolation of the nuclei and neurocellular degeneration in the hippocampus in rats, although this degeneration is distinct from that of Alzheimer's disease (Somova, 1996).

It has been postulated that the neuropathological effects observed in some of these studies may result from the increased bioavailability of aluminum administered as citrate and fluoride (ATSDR, 1999).

A study realized by Platt (Platt et al.,, 2001), whose goal was to immunocytochemically characterize the neurotosomovaxicity of aluminum in rats, revealed a concentration of aluminum in the white matter of the middle striatum and the corpus callosum

Intracerebroventricular administration of aluminum (5,4 $\mu \mathrm{g}$ ) was performed daily for 5 weeks in adult male rats. The results of this study showed that the neurotoxicity of aluminum at the brain level in rats affects both glial response and cholinergic projections, which is consistent with the observations of aluminum-induced cognitive defects in this species (Platt et al., 2001).

Hordeum vulgare is a good natural source of vitamins and minerals, and its extract is widely consumed as a functional food for health reasons (Yamaura, et al., 2015). They are a rich source of the powerful antioxidants saponarin and lutonarin (Benedet et al., 2007) and also have physiological activities, including lipidlowering (Yu et al., 2002a), anti-diabetic (Yu et al., 2002b), and anti-ulcer (Ohtake et al., 1985) effects, as well as an antidepressant effect in mice (Yamaura et al., 2012), via its antioxidant action.

In our study, the administration of HEV in intoxicated rats showed a considerable reduction $(62,62 \%)$ of $\mathrm{AICl} 3$ levels in the brain. Some studies indicate that $H$. vulgare is a good phytostabilization plant because of its capacity to accumulate heavy metals $(\mathrm{Cd}$ and $\mathrm{Hg})$ (Dago et al., 2014).

Entire grains are also an important dietary source of fat-soluble, water-soluble and water-insoluble antioxidants. These cereal antioxidants include: phytic acid, 

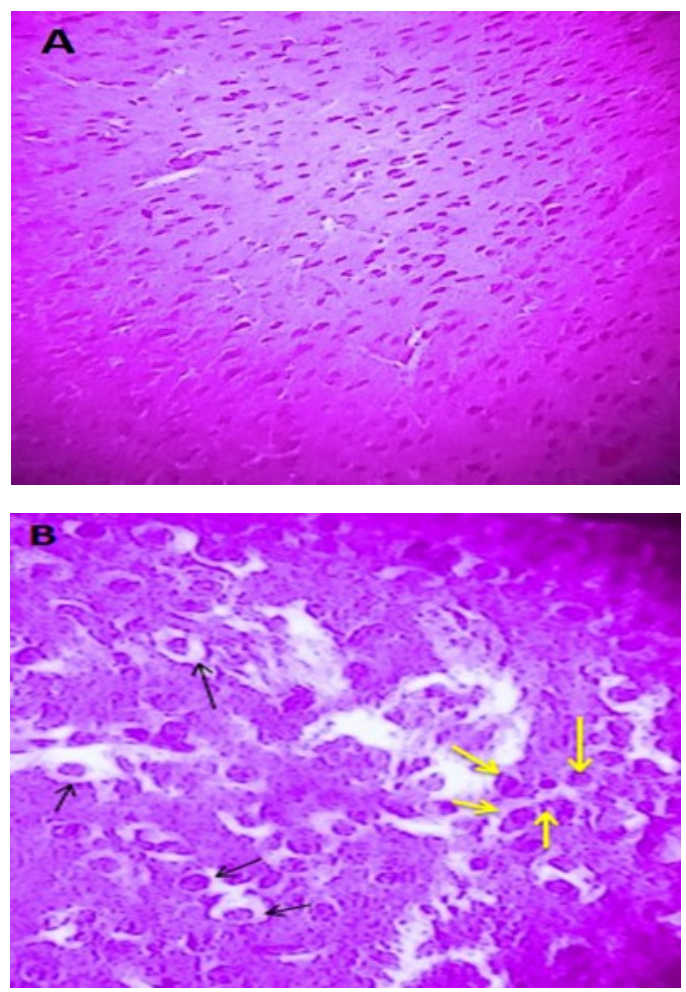
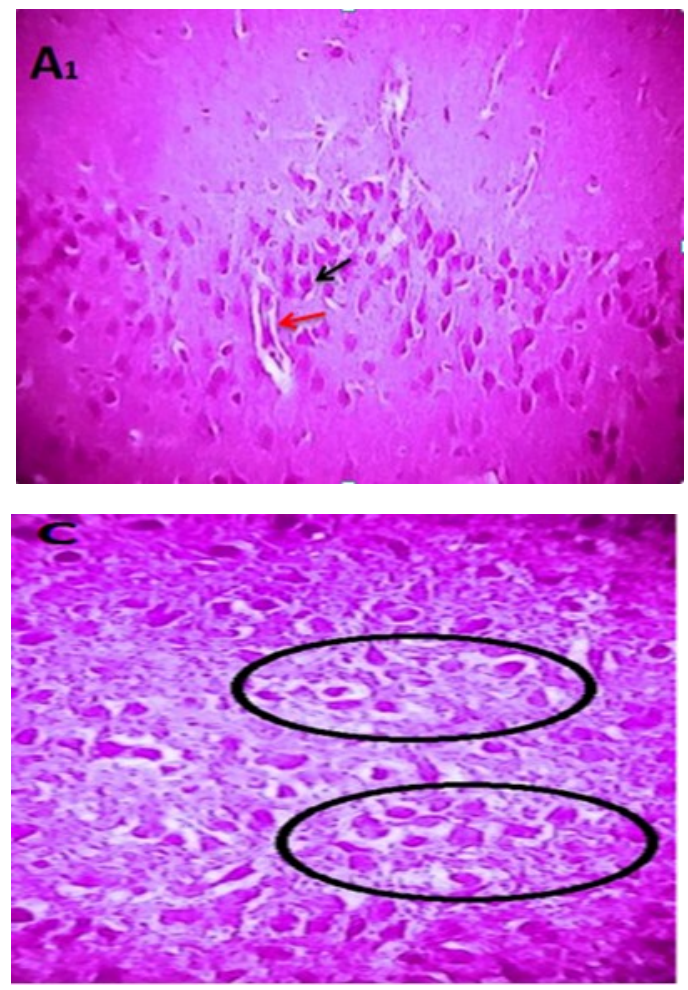

Fig. 1. Photomicroscopic view of hematoxylin and eosin G-stained cerebellar cortex tissue: (×40). A,A1: Sections of the cerebral cortex of control rats showing normal architecture, blood capillary (red arrow) and normal astrocyte cells (black arrow).B: Histological sections of a tissue of the cerebral cortex in intoxicated rats (A/Cl3) showing cellular necrosis (presence of eosinophils) (yellow arrow) and cellular spongiosis (black arrow). C: Histological sections of a tissue of the cerebral cortex in AlCl3 intoxicated rats treated with EAHV showing tissue oedema (circles) and absence of cell necrosis.

tocotrienols, phenolic acids, selenium and vitamin E. These multifunctional antioxidants are available throughout the gastrointestinal tract for a long period of time after consumption in immediate to slow-release forms. (Tsai et al., 2004; Webster, 2002).

The prophylactic efficacy of phytic acid can be attributed to its capacity to complex with multivalent cations. The rats treated preventively and curatively with PA exhibited significantly reduced levels of aluminum in the brain. Another reason that IP6 can chelate heavy metal ions, that it has twelve negatively charged hydroxyl groups makes PA a highly negatively charged molecule (Ferry et al., 2002; Daley et al., 2013). This suggests that PA can cross the blood-brain barrier and acts at the brain level. Sanchis and Adrover (2017) showed that PA binds to the surface of organs and is recovered from the blood. Cúneo et al. (2006). showed that the accumulation of heavy metals such as lead in bones, kidneys and liver was inversely proportional to the amount of phytate ingested. These data support the hypothesis that phytic acid may prevent excessive intestinal absorption and accumulation of aluminum in the tissues of laboratory animals. PA has been shown to reduce cadmium-induced toxicity in male rats (Tsao et al. 1997; Rimbach et al. 1998; Mohamed et al., 2015). In all cases, the known chelating ability of PA has been translated into its application as a detoxifying agent against heavy metals such as $\mathrm{Cd}$ and $\mathrm{Pb}$ (Sanchis and Adrover 2017; Reddy et al., 2000).

In addition, antioxidants can protect the body's cells from free radical damage. In this respect, antioxidants have the ability to neutralize the harmful effects of reactive oxygen species. There are different types of antioxidants among them enzymatic antioxidants, food -borne antioxidants and plant antioxidants. (Jan et al., 2015). As a result, plants contain a wide range of chemicals and antioxidants or bioactive molecules through which free radicals can be neutralized, thus preventing the progression of many chronic diseases induced by oxidative stress (Dehghan et al., 2011).

The European health grain project has started a collaborative study to evaluate cereal grains for the composition of bioactive compounds. This research group examined 10 barley varieties for antioxidants and other health-promoting compounds (Andersson et al., 2008). Antioxidants identified in barley include fat-soluble vitamins, including tocopherols and tocotrienols, phenolic compounds, flavonoïdes including proanthocyandins and anthocyandins, and alkylresorcinols (Shewry, 2014).

Treatment resulted in a significant increase in SOD, CAT and GPx activity in AICl3-exposed rats compared 
to that of intoxicated and untreated rats due to the antioxidant activity of barley. Our results are consistent with those of Akalin Ciftci et al. (2015) who found that barley extract also inhibited lipid peroxidation and increased antioxidant enzymes (GSH, SOD, and catalase) in rats fed a hyperlidic diet, and that barley extract $(H$. vulgare $L$.) had potent antioxidant activity (Thatiparthi et al.,2019).

Administration of $H$. vulgare extract in intoxicated rats showed that the treatment significantly improved brain architecture, to some extent, altered brain histopathology. Since Hordeum vulgare is known by its composition of polyphenols (Thatiparthi et al.,2019); polyphenols, including flavonoids, are well-known antioxidants. Recently, in a critical review of antioxidants, neuroprotective properties in the central nervous system of barley polyphenols have been reported (Giacalone et al., 2011). Barley also contains the flavonoids saponarin and lutonarin which have powerful antioxidant activities. These flavonoids are thought to be responsible for the biological activities of barley (Kamiyama and Shibamoto,2012).

\section{Conclusion}

The present study concluded that exposure to aluminum causes oxidative stress and brain dysfunction of Wistar rats by reducing the activity of various antioxidant enzymes (CAT, GPx and SOD). The histological study confirmed the results of this toxicity, which resulted in cell necrosis in the cerebellar cortex. The administration of HVE to rats previously intoxicated with aluminium chloride induced an improvement of all the studied parameters such as the enzymes of the oxidative status and rehabilitation of this system by improving the architecture of the brain. Thus, the neuro-protection against the harmful effects of aluminium was due to the bioactive molecules such as antioxidants found in the $H$. vulgare plant.

\section{REFERENCES}

1. Abdel Moneim, A.E. (2012). Evaluating the potential role of pomegranate peel in aluminium-induced oxidative stress and histopathological alterations in brain of female rats. Biol. Trace Elem. Res.150:328-336. DOI: 10.1007/ s12011-012-9498-2

2. Abdel-Wahab, W.M. (2012). AlCl3-induced toxicity and oxidative stress in liver of male rats: protection by melatonin. Life Sci J 9(4):1173-1182. http://www.lifes ciencesite.com

3. Abu-Serie, M. M., Habashy, N. H., \& Maher, A. M. (2019). In vitro anti-nephrotoxic potential of Ammi visnaga, Petroselinum crispum, Hordeum vulgare, and Cymbopogon schoenanthus seed or leaf extracts by suppressing the necrotic mediators, oxidative stress and inflammation. BMC Complementary and Mlternative medicine 19(1): 149.

4. Adli, D., Hachem, K., Benreguieg, M., Brahmi, M.,
KAHLOULA, K., Slimani, M. (2018). The efficiency of Syzygium aromaticum essential oil against renal intoxication by lead in rats during development. Bioscience Research 15(3): 2126-2133.

5. AFSSAPS:Agence française de sécurité sanitaire des produits de santé (2011). Assessment of the risk associated with the use of aluminum in cosmetic products. Saint -Denis. Rapp.

6. Akalin Çiftçi, G., Ertorun, I., Akalin, A., Alataş, I.O., Musmul, A. (2015). The effects ofatorvastatin on antioxidant/anti inflammatory properties of HDLs in hypercholesterolemics. Turk. J. Med. Sci. 45 (2): 345351. doi: 10.3906/sag-1311-91

7. Al-dalain, S., El-kutry, M. S., and Ibrahim, H. S. (2008). Inhibitory effect of aqueous extracts of barley and fenugreek on ulcer induction in rats. World Appl Sci J 5(3): 332 -9 .

8. Al-Kahtani, M.A. (2010). Renal damage mediated by oxidative stress in mice treated with aluminum chloride: Protective effect of Taurine. J. Biol. Sci. 10(7):584-595.

9. Al-Olayan, E. M., El-Khadragy, M. F. and Abdel Moneim, A. E. (2015). The protective properties of melatonin against aluminium $\square$ induced neuronal injury. International journal of experimental pathology, 96(3): 196-202. doi: 10.1111/iep.12122

10.Andersson, A.A.M., Lampi, A.-M., Nyström, L. et al. (2008). Phytochemical and dietary fiber components in barley varieties in the HEALTH GRAIN Diversity Screen. J. Agric. Food. Chem. 56 (21): 9767-9776. doi: 10.1021/ jf802037f.

11.ATSDR-Agency for Toxic Substances and Disease Registry (1999). Toxicological Profile for Aluminum. Atlanta, GA.: U.S. Department of Health and Human Services, Public Health Service; 1999. Internet: http:// www.atsdr.cdc.gov/toxprofiles/tp22.html

12.Bai, C.S., Wang, F., Zhao, H.S., Li, Y.F. (2012). Effects of Subchronic Aluminum Exposure on Liver Function in Rats. J. Northeast Agric. Univ. 19(2) :62-65. https:// doi.org/10.1016/S1006-8104(13)60039-2

13.Bancroft, J.D. (1975). Histopathological stains and their diagnostic uses. Edinburgh London and New York: Churchill Livingstone.

14.Behall, K.M., D.J. Scholfield and J. Hallfrisch, (2004). Diets containing barley significantly reduce lipids in mildly hypercholesterolemic men and women. Am. J.Clin. Nutr, 80: 1185-93. doi: 10.1093/ajcn/80.5.1185.

15.Benedet, J.A., Umeda, H., Shibamoto, T. (2007) Antioxidant activity of flavonoids isolated from young green barley leaves toward biological lipid samples. $J$ Agric Food Chem,55:5499-504. doi: 10.1021/jf070543t.

16.Bhadauria M. (2012) Combined treatment of HEDTA and propolis prevents aluminum induced toxicity in rats. Food Chem. Toxicol.50, 2487-2495. https://doi.org/10.1016/ j.fct.2011.12.040

17.Chalansonnet, M., Carabin, N., Boucard, S., Merlen, L., Melczer, M., Antoine, G., Jerome, D., Aurelie, R., \& Gagnaire, F. (2018). Study of potential transfer of aluminum to the brain via the olfactory pathway. Toxicology Letters, 283: 77-85. doi: 10.1016/j.toxlet.2017.11.027.

18.Cúneo, F., Amaya-Farfan, J., \& Morgano, M. A. (2006). Dietary phytates protect the rat against lead toxicity- 
Journal of Food Agriculture and Environment, 4(3/4): 45.

19.Dago, À., González, I., Ariño, C., Díaz-Cruz, J. M., \& Esteban, M. (2014). Chemometrics applied to the analysis of induced phytochelatins in Hordeum vulgare plants stressed with various toxic non-essential metals and metalloids. Talanta. 118: 201-209. doi: 10.1016/ j.talanta.2013.09.058.

20.Daley, T., Omoregie, S. N., Wright, V. and Omoruyi, F. O. (2013). Effects of phytic acid and exercise on some serum analytes in rats orally exposed to diets supplemented with cadmium. Biological Trace Element Research, 151(3): 400-405. doi: 10.1007/s12011-012-9572-9.

21.Dehghan, K. A., Rasooli, I., Rezaee, M.B., Owlia, P. (2011). Antioxidative properties and toxicity of white rose extract. Iranian J Toxicol, 5(12):415-425.

22.Domingo, J.L., Llorens, J., Sanchez, D.J., Gomez, M., Llobet, J.M., Corbella, J.(1996). Age-related effects of aluminum ingestion on brain aluminum accumulation and behavior in rats. Life Sc.i, 58(17):1387-1395. doi: 10.1016/0024-3205(96)00108-7.

23. Esparza, J.L., Gomez, M., Rosa, N. M., Paternain, J.L., Mallol, J., Domingo, J.L. (2005).Melatonin reduces oxidative stress and increases gene expression in the cerebral cortex and cerebellum of aluminum-exposed rats. J Pineal Res, 39(2):129-136. doi: 10.1111/j.1600079X.2005.00225.X.

24.Ferry, S., Matsuda, M., Yoshida, H., \& Hirata, M. (2002). Inositol hexakisphosphate blocks tumor cell growth by activating apoptotic machinery as well as by inhibiting the Akt/NFkBmediated cell survival pathway. Carcinogenesis, 23(12): 2031-2041.

25.Fonta, C., Negyessy, L., Renaud, L., et al. (2005). Postnatal development of alkaline phosphatase activity correlates with the maturation of neurotransmission in the cerebral cortex. J Comp Neurol,486:179-96. doi: 10.1002/cne.20524.

26.Food and Drug Administration (FDA). (2002). Food labeling: health claims, soluble dietary fiber from certain foods and coronary heart disease, Intl. Rule. Fed. Reg., 67: 61773-61783

27.Giacalone, M., Di Sacco, F., Traupe, I., Topini, R., Forfori, F., Giunta, F. (2011). Antioxidant and neuroprotective properties of blueberry polyphenols: A critical review. Nutr Neurosci,14:119-25. doi: 10.1179/1476830511Y.0000000007.

28.Jan, A.T., Azam, M., Siddiqui, K., Ali, A., Choi, I., Haq, Q.M. (2015). Heavy metals and human health: mechanistic insight into toxicity and counter defense system of antioxidants. Int J Mol Sci, 16(12): 2959229630. doi: 10.3390/ijms161226183.

29.Jollow, D.J., Mitchell, J.R., Zampaglione, N., et al. (1973). Bromobenzene-induced liver necrosis. Protective role of glutathione and evidence for 3,4bromobenzene oxide as the hepatotoxic metabolite. Pharmacology, 11:151-69. https://doi.org/10.1159/0 001 36485

30.Kakkar, P., Das, B., Viswanathan, P.N. (1984). A modified spectrophotometric assay of superoxide dismutase. Indian J Biochem Biophys, 21:130-2. http:// hdl.handle.net/123456789/19932

31.Kalaiselvi, A., Suganthy, O.M., Govindassamy, P.,
Vasantharaja, D.,Gowri, B., Ramalingam, V. (2014). Influence of aluminium chloride on antioxidant system in the testis and epididymis of rats. Iranian $J$ Toxicol., 8 (24):991-997.

32. Kamiyama, M., Shibamoto, T. (2012). Flavonoids with potent antioxidant activity found in young green barley leaves. J Agric Food Chem, 60:6260-7. doi: 10.1021/ jf301700j.

33.Kaur, T., Bijarnia, R.K., Nehru, B.(2009). Effect of concurrent chronic exposure of fluoride and aluminum on rat brain. Drug Chem Toxicol, 32(3):215-221. doi: 10.1080/01480540902862251.

34.Kumar, A., Dogra, S., \& Prakash, A. (2009). Protective effect of curcumin (Curcuma longa), against aluminium toxicity: Possible behavioral and biochemical alterations in rats. Behavioural Brain Research, 205(2): 384-390. https://doi.org/10.1016/j.bbr.2009.07.012

35.Liaquat, L., Sadir, S., Batool, Z., Tabassum, S., Shahzad, S., Afzal, A., \& Haider, S. (2019). Acute aluminum chloride toxicity revisited: Study on DNA damage and histopathological, biochemical and neurochemical alterations in rat brain. Life Sciences, 217: 202-211. https:// doi.org/10.1016/j.lfs.2018.12.009

36.Mohamed, T. M., Salama, A. F., Nimr, T. M. E., \& Gamal, D. M. E. (2015). Effects of phytate on thyroid gland of rats intoxicated with cadmium. Toxicology and Industrial Health, 31(12): 1258-1268. doi: 10.1177/07482 3371 3485887.

37.Murtaugh, M.A., D.R. Jacobs and B. Jacob. (2003). Epidemiological support for the protection of whole grains against diabetes. J. Proc. Nut. Soc., 62: 143-9. doi: 10.1079/pns2002223.

38.Nehru, B., Anand, P.(2005). Oxidative damage following chronic aluminium exposure in adult and pup rat brains. $J$ Trace Elem. Med. Biol.,19(2-3):203-208. doi: 10.1016/ j.jtemb.2005.09.004.

39. Ohtake, H., Yuasa, H., Komura, C., Miyauchi, T., Hagiwara, Y., Kubota, K.( 1985). Studies on the constituents of green juice from young barley leaves. Antiulcer activity of fractions from barley juice. Yakugaku Zasshi,105:1046-51. doi: 10.1248/ yakushi1947.105.11_1046.

40.Platt, B., Fiddler, G., Riedel, G., Henderson, Z.(2001). Aluminium toxicity in the rat brain: histochemical and immunocytochemical evidence. Brain Res. Bul.I, 55 (2):257-67. doi: 10.1016/s0361-9230(01)00511-1.

41.Rebaya, A., Belghith, S. I., Baghdikian, B., Leddet, V. M., Mabrouki, F., Olivier, E., \& Ayadi, M. T. (2014). Total phenolic, total flavonoid, tannin content, and antioxidant capacity of Halimium halimifolium (Cistaceae). Journal of Applied Pharmaceutical Science, 5(1): 52-57. DOI: 10.7324/JAPS.2015.50110

42.Reddy, G. R., \& Zawia, N. H. (2000). Lead exposure alters Egr-1 DNA-binding in the neonatal rat brain. International Journal of Developmental Neuroscience, 18(8): 791 -795. doi: 10.1016/s0736-5748(00)00048-4.

43.Rimbach, G., Walter, A., Most, E., \& Pallauf, J. (1998). Effect of microbial phytase on zinc bioavailability and cadmium and lead accumulation in growing rats. Food and Chemical Toxicology, 36(1): 7-12. doi: 10.1016/s02786915(97)00117-8. 
44. Rotruck, J.T., Pope, A.L., Ganther, H.E., Swanson, A.B., Hafeman, D.G., Hoekstra, W.G. (1973). Selenium Science, 179:588-90

45. Samet, J.M., Wages, P.A. (2018). Oxidative stress from environmental exposures. Curr Opin Toxicol, 7:60-66. https://doi.org/10.1016/j.cotox.2017.10.008

46.Sánchez-Iglesias, S., Méndez-Alvarez, E., IglesiasGonzález, J., Muñoz-Patiño, A., Sánchez-Sellero, I., Labandeira-García, J.L., Soto-Otero, R. (2009). Brain oxidative stress and selective behaviour of aluminium in specific areas of rat brain: potential effects in a 6-OHDAinduced model of Parkinson's disease. J Neurochem., 109 (3):879-888. https://doi.org/10.1111/j.1471-4159.2009.06 019.x

47.Sanchez-Iglesias, S., Soto-Otero, R., Iglesias-Gonzalez, J., Barciela-Alonso, M.C., Bermejo-Barrera, P., MendezAlvarez, E.(2007). Analysis of brain regional distribution of aluminium in rats via oral and intraperitoneal administration. J Trace Elem Med Biol., 21(Suppl 1):3134. https://doi.org/10.1016/j.jtemb.2007.09.010

48.Sanchis, P., \& Adrover, M. (2017). Phytate: a pharmacological swiss army knife with potential against protein glycation. Current Trends in Biomedical Engineering \& Biosciences, 5: 85-88

49.Sefidkon, F., Jalili, A., \& Mirhaji, T. (2002). Essential oil composition of three Artemisia spp. from Iran. Flavour and Fragrance Journal, 17(2): 150-152.

50.Sharma, D., Sethi, P., Hussain, E., Singh, R.(2009). Curcumin counteracts the aluminium-induced ageingrelated alterations in oxidative stress, $\mathrm{Na}+\mathrm{K}+$ ATPase and protein kinase $\mathrm{C}$ in adult and old rat brain regions. Biogerontology, 10(4):489-502. https://doi.org/10.1007/ s10522-008-9195-x

51.Shewry, P.R. (2014). Minor components of the barley grain: minerals, lipids, terpenoids, phenolics, and vitamins. In: Barley: Chemistry and Technology, 2e (ed. P.R.Shewry and S.E. Ullich), 161-192. St Paul: AACCI.

52.Sinha, A.K. (1972). Colorimetric assay of catalase. Anal Biochem 47:389-94.

53.Sitayeb, T., \& Belabbes, I. (2018). Landscape Change in the Steppe of Algeria South-West Using Remote Sensing. Annals of Valahia University of Targoviste, Geographical Series, 18(1), 41-52.DOI: 10.2478/avutgs-2018-0005

54.Somova, L.I., Khan, M.S.(1996). Aluminium intoxication in rats. II. Chronic toxicity: effects on aluminium balance, aluminium plasma and tissue levels and haematology. S Afr J Food Sci and Nutrition, 8(3):102-5.

55.Taus, N., Farraj, M., Tănase, S., Mironescu, A., Boicu, M., Necula, V., Taus, L. (2013). Aluminum - a chemical neurotoxic agent. Bulletin of the Transilvania University of Braşov Series VI. Med. Sci, 2(55):1-8.
56.Thatiparthi, J., Dodoala, S., Koganti, B., \& KVSRG, P. (2019). Barley grass juice (Hordeum vulgare L.) inhibits obesity and improves lipid profile in high-fat diet-induced rat model. Journal of ethnopharmacology 238: 111843. https://doi.org/10.1016/j.jep.2019.111843

57.Tsai, C.J., Leitzmann, M.F., Willett, W.C., and Giovannucci, E.L. (2004). Long-term intake of dietary fiber and decreased risk of cholecystectomy in women. Am. J. Gastroenterol. Jul, 99(7): 1364-70. doi: 10.1111/j.15720241.2004.30153.x.

58.Tsao, G. T., Zheng, Y., Lu, J., \& Gong, C. S. (1997). Adsorption of heavy metal ions by immobilized phytic acid. Applied Biochemistry and Biotechnology, 63(1): 731. doi: 10.1007/BF02920471.

59.Turkez, H., Yousef, M.I., Geyikoglu, F. (2010). Propolis prevents aluminum induced genetic and hepatic damages in rat liver. Food Chem.Toxicol, 48: 2741-2746. doi: 10.1016/j.fct.2010.06.049.

60.Webster, F.H. (2002). Whole-grain oat and oat products: In Whole- Grain Foods in Health and Disease, eds L. Marquart, J. Slavin et al. American Association of Cereal Chemists, St. Paul, MN, pp: 83124.

61. Yamaura, K., Nakayama, N., Shimada, M., Bi, Y., Fukata, H., Ueno, K.( 2012). Antidepressant-like effects of young green barley leaf (Hordeum vulgare L.) in the mouse forced swimming test. Pharmacognosy Res., 4:22-6. doi: 10.4103/0974-8490.91030

62.Yamaura, K., Tanaka, R., Bi, Y., Fukata, H., Oishi, N., Sato, H., Chisato, M., \& Ueno, K. (2015). Protective effect of young green barley leaf (Hordeum vulgare L.) on restraint stress-induced decrease in hippocampal brainderived neurotrophic factor in mice. Pharmacognosy Magazine, 11(Suppl 1): S86. doi: 10.4103/0973-1296.157702

63.Yu, Y.M., Chang, W.C., Chang, C.T., Hsieh, C.L., Tsai, C.E.( 2002b). Effects of young barley leaf extract and antioxidative vitamins on LDL oxidation and free radical scavenging activities in type 2 diabetes. Diabetes Metab.,28:107-14.

64.Yu, Y.M., Wu, C.H., Tseng, Y.H., Tsai, C.E., Chang, W.C. (2002a). Antioxidative and hypolipidemic effects of barley leaf essence in a rabbit model of atherosclerosis. Jpn J Pharmacol,89:142-8. doi: 10.1254/jjp.89.142.

65.Yuan, C. Y., Lee, Y. J. and Hsu, G. S. W. (2012). Aluminum overload increases oxidative stress in four functional brain areas of neonatal rats. Journal of Biomedical Science, 19(1): 1-9. doi: 10.1186/1423-0127-19-51.

66.Zhou, m. (2010). Barley production and consumption. In: zhang, g. and li, c. (eds) Genetics and Improvement of Barley Malt Quality. Hangzhou: Zhejiang University Press; Berlin/Heidelberg: Springer 